\title{
The emergence of YMDD mutants precedes biochemical flare by 19 weeks in lamivudine-treated chronic hepatitis B patients: an opportunity for therapy reevaluation
}

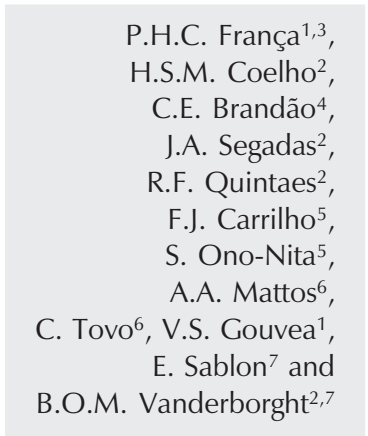

Correspondence

P.H.C. França

Departamento de Medicina

Univille

Caixa Postal 246

89201-972 Joinville, SC

Brasil

Fax: +55-47-3473-0131

E-mail:phfranca@terra.com.br

Research supported in part by grants from Innogenetics and Instituto de Diagnóstico Molecular Theranostica (IDMT). P.H.C. França was the recipient of a fellowship from CAPES.

Publication supported by FAPESP. $\ldots \ldots \ldots \ldots \ldots \ldots \ldots$

Received January 10, 2007 Accepted June 4, 2007

\author{
'Departamento de Virologia, Instituto de Microbiologia, \\ ${ }^{2}$ Departamento de Gastroenterologia, Hospital Universitário Clementino Fraga Filho, \\ Universidade Federal do Rio de Janeiro, Rio de Janeiro, RJ, Brasil \\ ${ }^{3}$ Departamento de Medicina, Universidade da Região de Joinville, Joinville, SC, Brasil \\ ${ }^{4}$ Departamento de Gastroenterologia, Hospital Universitário Gaffree Guinle, \\ Universidade do Rio de Janeiro (Uni-Rio), Rio de Janeiro, RJ, Brasil \\ ${ }^{5}$ Departamento de Gastroenterologia, Faculdade de Medicina, \\ Universidade de São Paulo, São Paulo, SP, Brasil \\ ${ }^{6}$ Departamento de Medicina Interna, \\ Fundação Faculdade Federal de Ciências Médicas de Porto Alegre, \\ Porto Alegre, RS, Brasil \\ ${ }^{7}$ Innogenetics NV, Ghent, Belgium
}

\section{Abstract}

Given the loss of therapeutic efficacy associated with the development of resistance to lamivudine (LMV) and the availability of new alternative treatments for chronic hepatitis B patients, early detection of viral genotypic resistance could allow the clinician to consider therapy modification before viral breakthrough and biochemical relapse occur. To this end, 28 LMV-treated patients ( $44 \pm 12$ years; $24 \mathrm{men}$ ), on their first therapy schedule, were monitored monthly at four Brazilian centers for the emergence of drug resistance using the reverse hybridization-based INNO-LiPA HBV DR assay and occasionally sequencing (two cases). Positive viral responses (HBV DNA clearance) after 6,12 , and 18 months of therapy were achieved by 57,68 , and $53 \%$ of patients, while biochemical responses (serum alanine aminotransferase normalization) were observed in 82,82 , and $53 \%$ of cases. All viral breakthrough cases $(\mathrm{N}=8)$ were related to the emergence of YMDD variants observed in 7,21, and 35\% of patients at 6,12 , and 18 months, respectively. The emergence of these variants was not associated with viral genotype, $\mathrm{HBeAg}$ expression status, or pretreatment serum alanine aminotransferase levels. The detection of resistanceassociated mutations was observed before the corresponding biochemical flare ( $41 \pm 14$ and $60 \pm 15$ weeks) in the same individuals. Then, if highly sensitive LMV drug resistance testing is carried out at frequent and regular intervals, the relatively long period $(19 \pm 2$ weeks) between the emergence of viral resistance and the onset of biochemical relapse can provide clinicians with ample time to reevaluate drug therapy.
Key words

- Hepatitis B

- Antiviral therapy

- Lamivudine

- Drug resistance

- YMDD variants

- Hepatitis B virus

..................... 


\section{Introduction}

Hepatitis B virus (HBV) infection remains a major international public health concern leading to more than 500,000 deaths annually worldwide. The World Health Organization estimates that almost 400 million people are chronic carriers $(1,2)$, despite the availability of effective prophylactic vaccines (3).

In the last decade, substantial advances have been made in the treatment of chronic hepatitis B using drugs such as the immunomodulator interferon- $\alpha$, the nucleoside analogue inhibitor lamivudine, and, more recently, the analogue inhibitors adefovir dipivoxil and entecavir (4-7). The nucleoside/tide analogue-based drugs have been preferred in Brazil because of their negligible side effects and low cost $(8,9)$.

Lamivudine has proven to be effective in all stages of the disease from acute infection to virus-related decompensated cirrhosis. Unfortunately, the emergence of lamivudineresistant HBV variants is the main concern with this treatment. The most common mutation, located in the YMDD conserved motif of the segment coding for the reverse transcriptase activity of the viral polymerase gene, results in the substitution of $\mathrm{Met}^{204}$ for Val or Ile (rtM204V/I). Genotypic resistance can be detected in 14-32\% of patients after 1 year of therapy, increasing to $69 \%$ after 5 years $(8,10)$. The clinical course of patients with YMDD variants is variable. However, resistance is usually related to a breakthrough event (increase in the HBV DNA and serum alanine aminotransferase (ALT) levels after initial viral suppression and biochemical normalization, respectively). Some patients continue to benefit from the maintenance of lamivudine therapy after detection of viral resistance, showing lower HBV DNA and serum ALT levels compared to pretreatment values. However, over time, most of the patients have increased rates of hepatitis flare, decreased rates of sustained therapeutic response, and worsening of liver histology. This is seen especially when compensatory mutations (e.g., L180M), which can partially restore the viral replication ability, are co-selected during long-term treatment (11-13).

In most cases, lamivudine continues to be the first choice for chronic hepatitis B therapy, mainly due to its relatively low cost $(9,14)$. Thus, the objective of the present study was to determine the time lag between the detection of YMDD variants and the emergence of biochemical rebound during lamivudine therapy in order to optimize treatment.

\section{Patients, Material and Methods}

\section{Patients and samples}

Twenty-eight well-characterized chronically infected hepatitis B patients were longitudinally and prospectively followed up for a 12- to 18-month study period while on first-time lamivudine (Epivir, GlaxoSmithKline, Research Triangle Park, NC, USA) therapy (150 mg orally, once a day). Eleven individuals withdrew spontaneously from the study after one year and before 18 months of follow-up due to a variety of individual reasons. None were HIV and/or HCV carriers. Patients were enrolled at the following four Brazilian regional reference centers for chronic hepatitis treatment: Hospital Universitário Clementino Fraga Filho $(\mathrm{N}=6)$ and Hospital Universitário Gaffree Guinle ( $\mathrm{N}=10$ ), Rio de Janeiro, RJ, Hospital das Clínicas ( $\mathrm{N}=8)$, São Paulo, SP, and Instituto Santa Casa de Misericórdia $(\mathrm{N}=4)$, Porto Alegre, RS. All presented clinical or biochemical signs of chronic active hepatitis and the decision to treat was made by local medical specialists according to Brazilian treatment guidelines (9). Pretreatment and monthly scheduled serum samples were collected during routine clinical visits and stored at $-20^{\circ} \mathrm{C}$ until transport and subsequent anal- 
ysis. The study protocol was approved by the local Ethics Committees of each hospital and written informed consent was obtained from all patients.

Serological, biochemical, and viral testing for hepatitis $B$ virus

For each available sample, serological tests were performed for the detection of HBV infection markers by commercial enzyme immunoassays (HBsAg, anti-HBs, and anti-HBc, Abbott Laboratories, Abbott Park, IL, USA; HBeAg and anti-HBe, Organon Teknika, Durham, NC, USA). Liver biochemistry was monitored by means of serum ALT quantification performed by routine automated titration. Biochemical flare (relapse) was defined as an increase in ALT levels exceeding three times the upper limit of normality (ULN) from normal levels in the preceding samples, after excluding other drug-induced or alcoholic hepatitis.

HBV DNA was isolated from the samples using the QIAamp DNA Mini Kit (Qiagen, Westburg, The Netherlands) and partial genome amplification by qualitative nested PCR (lower detection limit of 500 copies/ $\mathrm{mL}$ ), as described elsewhere (15). The 5'biotinylated primers employed were designed to encompass the $\mathrm{B}$ and $\mathrm{C}$ domains of the viral polymerase gene as well as, due to overlapping reading frames, part of HBsAg gene with marked heterogeneity among genotypes. Pretreatment PCR-positive samples were tested for HBV genotype using a reverse hybridization line probe assay which differentiates genotypes A to H (INNO-LiPA HBV Genotyping, Innogenetics, Ghent, Belgium) (16). HBV DNA breakthrough was defined by the reappearance of viral DNA as determined by PCR.

\section{Monitoring emergence of YMDD mutants}

The emergence of $\mathrm{rtM} 204 \mathrm{~V} / \mathrm{I}$ and rtL180M mutations was investigated by an- other line probe assay (INNO-LiPA HBV DR, Innogenetics) in all HBV DNA-positive samples (15). Both hybridization assays were simultaneously performed using semi-automated procedures of the Auto-LiPA instrument (Innogenetics). Some selected samples had their LiPA results additionally confirmed by automated DNA sequencing of the corresponding amplicon at Innogenetics, by using the second-round primers and the $\mathrm{ABI}$ Prism BigDye terminator cycle sequencing reaction kit (Applied Biosystems, Foster City, CA, USA). Sequence comparisons were performed using the BioEdit version 7.0.1 software package (17).

\section{Statistical analysis}

Statistical analysis was performed using the Epi-Info version 3.2.2 program. Differences in proportions were tested by the Fisher exact test. Continuous ordinal data were compared by the non-parametric Mann-Whitney test. P values of 0.05 or less were considered to be significant.

\section{Results}

\section{Epidemiological and serological profiles}

Twenty-eight Brazilian patients with chronic hepatitis B fulfilled the minimum requirements of the study protocol. This group consisted of 4 women (14\%) and 24 men (86\%), with Caucasian (75\%), Black (18\%), or Asian (7\%) background, aged 44 \pm 12 years ( 22 to 65 years) at the beginning of lamivudine therapy.

Pretreatment serum samples from all participants, obtained $5 \pm 6$ weeks before the beginning of therapy, were available for serological and biochemical evaluation. All individuals displayed $\mathrm{HBsAg}$ and anti-HBc reactivities, and none was found to be antiHBs-positive. Regarding the HBeAg/anti$\mathrm{HBe}$ status at baseline, 12 patients were $\mathrm{HBeAg}$-positive and 16 had anti-HBe anti- 
bodies. Twenty-two of 28 patients (79\%) showed higher than normal serum ALT levels and 13 of them (46\%) exceeded two times the ULN.

\section{Prevalence of hepatitis B virus genotypes}

HBV genotype identification was performed on serum samples collected just prior to lamivudine treatment. HBV DNA was detected in all pretreatment serum samples, and the viral genotypes observed in the studied population were genotypes A $(68 \%, 19 /$ $28), \mathrm{D}(21 \%, 6 / 28), \mathrm{C}(7 \%, 2 / 28)$, and F (4\%, $1 / 28)$. Genotype $C$ variants, which are uncommon in South America, were found in samples from patients of Asian origin. The observed distribution of genotypes compared to pretreatment ALT levels or HBeAg status showed no relevant differences.

\section{Response to therapy}

The biochemical (ALT) and viral (HBV DNA) responses to therapy at 6,12 , and 18 months of treatment are summarized in Table 1. The maximum biochemical (normalized serum ALT levels) and viral (undetectable HBV DNA by PCR) response rates to therapy were observed at the end of 1 year of

Table 1. Biochemical and virologic response rates after 6, 12, and 18 months of lamivudine therapy.

\begin{tabular}{lccc}
\hline Response & \multicolumn{3}{c}{$\begin{array}{c}\text { Percentage of individuals } \\
\text { (number of individuals/total) }\end{array}$} \\
\cline { 2 - 4 } & 6 Months & 12 Months & 18 Months \\
\hline Biochemical & & & \\
$\quad$ Normal ALT level & $82 \%(22 / 27)$ & $82 \%(23 / 28)$ & $53 \%(9 / 17)$ \\
$\quad$ ALT breakthrough & - & $7 \%(2 / 28)$ & $12 \%(2 / 17)$ \\
Virologic & $57 \%(16 / 28)$ & $68 \%(19 / 28)$ & $53 \%(9 / 17)$ \\
$\quad$ Undetectable HBV DNA & - & $14 \%(4 / 28)$ & $29 \%(5 / 17)$ \\
$\quad$ HBV DNA breakthrough & & & \\
Biochemical + virologic & $48 \%(13 / 28)$ & $75 \%(21 / 28)$ & $53 \%(9 / 17)$ \\
$\quad$ Normal ALT level and & & & \\
$\quad$ undetectable HBV DNA & &
\end{tabular}

$\mathrm{ALT}=$ alanine aminotransferase. treatment ( 82 and $68 \%$, respectively). By 18 months, both types of response had diminished, which is consistent with the observation of an increasing number of breakthrough cases. When combined biochemical and virologic parameters were taken into account, the response to lamivudine therapy reached 48,75 , and $53 \%$ at months 6,12 , and 18 of follow-up. At these same times, mean ALT levels were significantly reduced $(0.83 \pm$ $0.40,1.45 \pm 0.39,1.04 \pm 0.47$, respectively) when compared to pretreatment levels (4.62 $\pm 7.27 ; \mathrm{P}<0.05)$.

\section{Monitoring lamivudine resistance}

The complete typing of known polymorphisms at codons rt204 and rt180 was possible for all pretreatment serum samples either by reverse hybridization (26 samples) or amplicon sequencing (2 samples). These two samples with indeterminate LiPA results were from distinct individuals and mutations close to codons 204 and 180 (nt 732, $\mathrm{C}$ to $\mathrm{T}$, and nt $670, \mathrm{G}$ to $\mathrm{A}$, according to the reverse transcriptase conserved region) were observed. Isolated wild-type codons 204 (Met) and 180 (Leu) were found in all pretreatment samples analyzed.

During each therapy follow-up, patients were closely monitored for the emergence of lamivudine resistance-associated mutations rtM204V/I (YMDD variant) and concomitant rtL180M. Overall, one or more of these mutations were identified in 8 (29\%) of the 28 patients who received lamivudine for at least 1 year (Table 2). The hybridization test correctly identified HBV variants, isolated or mixed with wild-type virus, in consecutive samples from 7 of the 8 individuals, while the remaining mutation was identified by partial polymerase gene sequencing. In the latter case, the indeterminate LiPA results could be attributed to the rare occurrence of the concomitant double silent transitions - C732Tnt and T735Cnt - located in the vicinity of codon 204 (201 and 202, 
respectively) not recognized by the probes available in the test version employed. The identification of mutation rtM204I was confirmed in half of the eight cases in which the investigated variants emerged. The loss of rtM204I detection followed by rtM204V emergence was observed in one case (patient 7 - Table 2). No other changing pattern of YMDD variants was observed. Therefore, the rtM204V mutation was identified in 5 of 8 mutant cases, always accompanied by rtL180M.

The possibility of diverse influences such as $\mathrm{HBV}$ genotype, pretreatment $\mathrm{HBe} \mathrm{Ag}$ status, and ALT levels on preferential selection of lamivudine-resistant mutants was analyzed. HBV genotype A was identified in $88 \%$ (7/8) of positive cases for variant emergence, while these mutants could not be observed in the majority $(89 \%$; $8 / 9)$ of nonA genotype cases. However, this observation was not statistically significant. Mean pretreatment ALT levels were higher among patients who showed a viral response and did not develop lamivudine resistance. Similarly, YMDD variant emergence was found to be higher, albeit not significantly so, among pretreatment $\mathrm{HBeAg}$-positive individuals $(42 \% ; 5 / 12)$ than among those without the same marker $(19 \% ; 3 / 16)$.

The observed rates for the polymerase gene mutations increased with prolonged lamivudine exposure, reaching 7\% (2/28), $21 \%(6 / 28)$, and $35 \%(6 / 17)$ after 6,12 , and 18 months of treatment, respectively. The first two cases of lamivudine resistance were observed at week 23 of therapy (Table 2). The occurrence of viral breakthrough was only observed in patients with detectable YMDD variants; these mutations were not detected in serum samples from treatmentresponsive patients.

The emergence of YMDD variants was also associated with biochemical breakthrough. In such cases, ALT flares occurred after the identification of the corresponding resistant mutants. Nevertheless, ALT flares were not always observed among YMDD mutant carriers ( 3 of 8 cases of genotypic resistance emergence could not be related to biochemical breakthrough), as shown in Figure 1 and Table 1. A single episode of

\begin{tabular}{|c|c|c|c|c|c|c|c|c|c|}
\hline \multirow[t]{2}{*}{ Patient } & \multirow{2}{*}{$\begin{array}{c}\text { Age } \\
\text { (years) }\end{array}$} & \multirow{2}{*}{$\begin{array}{c}\text { HBV } \\
\text { genotype }\end{array}$} & \multicolumn{2}{|c|}{ YMDD variants } & \multicolumn{2}{|c|}{ Virologic follow-up } & \multicolumn{3}{|c|}{ Biochemical follow-up } \\
\hline & & & Mutation & $\begin{array}{l}\text { Detection } \\
\text { (weeks) }\end{array}$ & $\begin{array}{l}\text { Undetectable HBV } \\
\text { DNA (weeks) }\end{array}$ & $\begin{array}{l}\text { Breakthrough } \\
\text { (weeks) }\end{array}$ & $\begin{array}{l}\text { ALT normalization } \\
\text { (weeks) }\end{array}$ & $\begin{array}{l}\text { Breakthrough } \\
\text { (weeks) }\end{array}$ & $\begin{array}{c}\text { Peak of } \\
\text { ALT elevation }\end{array}$ \\
\hline 1 & 65 & A & $\begin{array}{l}\text { rtM204V } \\
\text { rtL180M }\end{array}$ & $\begin{array}{l}44 \\
44\end{array}$ & 26 & 44 & n.a. & 63 & 3.3 \\
\hline 2 & 44 & A & $\begin{array}{l}\text { rtM204V } \\
\text { rtL180M }\end{array}$ & $\begin{array}{l}33 \\
33\end{array}$ & n.o. & & n.o. & & \\
\hline 3 & 38 & A & $\begin{array}{l}\text { rtM204V } \\
\text { rtL180M }\end{array}$ & $\begin{array}{l}34 \\
34\end{array}$ & 8 & 34 & 12 & 51 & 19.2 \\
\hline 4 & 45 & A & rtM204I & 43 & 25 & 43 & 9 & 64 & 5.4 \\
\hline 5 & 55 & $A$ & rtM204I & 62 & 49 & 55 & n.a. & 82 & 3.3 \\
\hline 6 & 36 & A & $\begin{array}{l}\text { rtM204V } \\
\text { rtL180M }\end{array}$ & $\begin{array}{l}23 \\
33\end{array}$ & n.o. & & 11 & 41 & 5.3 \\
\hline 7 & 32 & A & $\begin{array}{l}\text { rtM204I } \\
\text { rtM204V } \\
\text { rtL180M }\end{array}$ & $\begin{array}{l}23 \\
53 \\
53\end{array}$ & $\begin{array}{c}\text { n.o. } \\
34\end{array}$ & 53 & 40 & & \\
\hline 8 & 48 & $\mathrm{D}$ & rtM204I & 45 & n.o. & & 19 & unknown & \\
\hline
\end{tabular}

Age reported is at the beginning of therapy. ALT = alanine aminotransferase; $n . a .=$ not applicable (displaying normal values since pretreatment); n.o. $=$ not observed; unknown $=$ therapy dropout after variant detection. 
ALT flare was observed in the five individuals without hepatic decompensation, and with peaks ranging from 3.3 to 19.2 times ULN.

The identification of variants associated with lamivudine resistance was significantly earlier ( $41 \pm 14$ weeks) than the subsequent biochemical breakthrough (60 \pm 15 weeks) in the same individuals $(\mathrm{P}<0.05)$, as illustrated in Figure 1. Therefore, when considering only patients who showed ALT exacerbation associated with previous YMDD variant detection, a relatively long but constant $(19 \pm 2$ weeks) time interval could be observed.

\section{Discussion}

Chronic hepatitis B patients receiving antiviral therapy should have their clinical status regularly monitored in order to prevent or minimize major drawbacks such as adverse events, noncompliance with therapy, or development of drug resistance. Classically, tests to measure ALT levels and viral load are used $(14,18)$. Recently, these tests have been complemented by research assays to determine viral genotype, monitor the emergence of antiviral drug resistance, and type variants related to $\mathrm{HBeAg}$-negative hepatitis. Such tests can also assess possible associations with the natural history of the infection or response to therapy $(3,19)$.

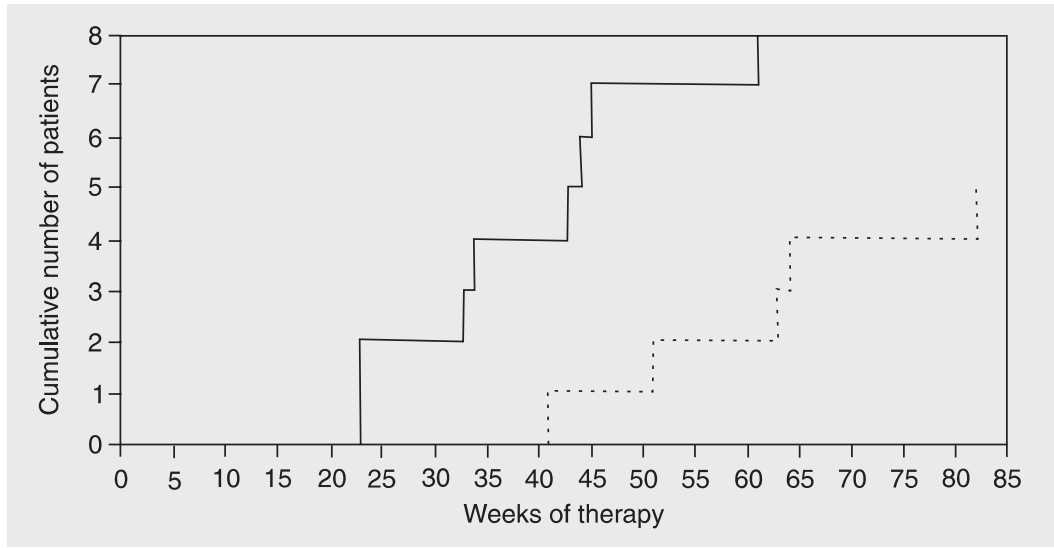

Figure 1. Biochemical breakthrough incidence (dotted line) and YMDD variant identification (full line) during lamivudine-based therapy.
In the present investigation, two commercially available reverse hybridizationbased assays were employed to define the viral genotype present in pretreatment samples and to identify the emergence of viral genotypic resistance during lamivudine treatment. In particular, the sensitivity of reverse hybridization tests allows the detection of the emergence of drug-resistance mutations, even when these represent only a small fraction of the total viral population $(20,21)$. This feature is especially important when evaluating the viral dynamics in response to therapeutic selection pressures (19).

In the present study, HBV genotyping was investigated in pretreatment serum samples. The possibility of superinfection during follow-up was not considered, mainly because the population studied did not include injecting drug users or individuals undergoing hemodialysis. Genotype A was clearly the most prevalent, followed by genotype $\mathrm{D}$, as already documented among most of the other groups of chronic carriers (excluding hemodialysis patients) in Brazil (22, 23).

The biochemical and viral response rates observed in the present study agreed with those reported in previous clinical trials, although these trials were carried out in widely diverse populations and under different treatment conditions $(11,24,25)$. Mean serum ALT levels were significantly reduced after 6,12 , and 18 months of lamivudine therapy when compared to the corresponding pretreatment values. Almost half of the patients showed pretreatment ALT levels of more than twice the ULN, a fact that is commonly associated with better response rates (14). Nevertheless, the present biochemical and viral response rates did not differ significantly with respect to pretreatment ALT levels. A lack of correlation between response rates and pretreatment serum ALT levels has been observed by others $(26,27)$.

The viral response rate of the patients who were $\mathrm{HBeAg}$-negative before starting 
lamivudine therapy was higher than that observed among HBeAg-positive individuals, but the difference was not statistically significant. Da Silva et al. (26) concluded that pretreatment $\mathrm{HBeAg}$ negativity could be considered as a positive predictive factor for response to lamivudine therapy in patients with chronic hepatitis B, even in cases of high viremia. On the other hand, the number of HBV DNA breakthrough cases by the end of follow-up was significantly different between pretreatment $\mathrm{HBeAg-negative} \mathrm{and}$ -positive individuals $(6.3 \%$; $1 / 16$ and $41.7 \%$; $5 / 12$, respectively). Considering that $\mathrm{HBV}$ DNA levels were not monitored, and given the results mentioned above, the possibility of an indirect influence of intrinsically lower levels of replication attributable to $\mathrm{HBeAg}$ non-expressing variants cannot be excluded $(18,28)$.

Wild-type codons rt204 (Met) and rt180 (Leu) were identified in all pretreatment samples, which is consistent with the paucity of citations of YMDD variant detection without previous lamivudine exposure (29). The two hybridization-based typing failures observed indicated rare polymorphisms (nt $732, \mathrm{C}$ to $\mathrm{T}$ - codon 201 , and nt $670, \mathrm{G}$ to $\mathrm{A}$ - codon 182) adjacent to the YMDD region, which were confirmed by sequencing. These single-nucleotide substitutions could have negatively affected the hybridization with probes included in the version of the LiPA assay employed and were seen repeatedly in samples from the same individuals taken during treatment.

HBV mutants carrying rtM204V or rtM204I developed among 14\% (4/28) and $18 \%(5 / 28)$ of patients, respectively, at the end of follow-up. One case of rtM204I rtI204V alternation was clearly identified. The compensatory mutation rtL180M (located in the B domain of viral reverse transcriptase) was detected, concomitantly or shortly after (Table 2) in samples from the same individuals in which rtM204V was observed, i.e., the frequent association be- tween rtM204V and rtL180M was reproduced $(30,31)$. Some investigators have reported that the M204I variant would be detected generally earlier than M204V $(32,33)$ but, despite the case of variants alternation mentioned above, this was not observed in the present study.

Most individuals who developed YMDD variants were infected with HBV genotype A. This, however, does not necessarily mean that genotype A-infected patients have a higher risk of developing YMDD variants since there was a high prevalence of genotype A in the population studied. No correlation was observed between HBV genotype and predisposition to the development of YMDD variants. Other studies involving larger numbers of patients have also failed to detect an association between HBV genotypes and YMDD variants (34-36).

The resistance-associated mutations also were not significantly related to pretreatment ALT levels or HBeAg-expression status, although the emergence rates of variants were higher among low-level ALT and $\mathrm{HBeAg}$-positive individuals. In contrast, according to Yuen et al. (37), patients with elevated ALT levels after HBV DNA breakthrough with YMDD mutants have significantly higher pretreatment ALT levels.

Genotypic resistance to lamivudine has usually been reported in approximately one quarter of patients after 1 year of treatment, rising to above $40 \%$ after the 2 nd year of exposure $(1,13)$. The emergence rates of YMDD variants observed in the present investigation after 6,12 , and 18 months of therapy were in close agreement with these findings $(10,24)$.

A strong association between viral breakthrough and genotypic resistance to lamivudine was confirmed: viral breakthrough was observed only among patients in whom the viral YMDD variant emergence was detected. Breakthroughs related to noncompliance, reported by some investigators (8) as being responsible for up to $30 \%$ of HBV break- 
throughs in lamivudine-treated patients, were not seen. Additionally, ALT levels exceeding at least three times the ULN (biochemical flare) after development of resistance were detected in 5 of 8 viral breakthrough cases. ALT flares unrelated to the emergence of YMDD variants were not observed in our study. It is now well known that the development of YMDD mutants is usually associated with serum ALT elevation even in immunocompetent patients, but that this event can be missed if serum sampling is infrequent.

The absence of the detection of biochemical relapse in 3 of the 8 patients with lamivudine genotypic resistance could be attributed to diverse factors: patient 2 did not show an on-treatment biochemical response and, therefore, should not be categorized as a biochemical relapser after rtM204V identification; patient 8 was not followed up (he withdrew from study after rtM204I detec- tion), and patient 7 did not show a biochemical flare until 6 months after the appearance of the rtM204I (week 23 of therapy) and rtM204V (week 53) mutants. In the latter case, the possibility of delayed biochemical breakthrough (up to 24 months) cannot be excluded, as reported by Papatheodoridis et al. (38).

The frequent (monthly) sampling performed in the present study allowed early detection of the emergence of lamivudineresistant strains. In the cases in which an association between YMDD variant emergence and ALT flare was observed, the former was achieved significantly earlier (19 \pm 2 weeks) than the latter in the same individuals. Using somewhat different protocols and methodologies as summarized in Table 3, other studies have revealed comparable results. Additionally, in view of our results and those of others $(14,31)$, the investigation of genotypic resistance emer-

Table 3. Time gap between YMDD variant identification and associated biochemical relapse in chronic hepatitis B patients under lamivudine therapy, reported by different investigators.

\begin{tabular}{|c|c|c|c|c|c|c|}
\hline \multirow[t]{3}{*}{ Reference or source } & \multirow[t]{3}{*}{$\mathrm{N}$} & \multicolumn{2}{|c|}{ YMDD variants monitoring } & \multirow{2}{*}{\multicolumn{2}{|c|}{$\begin{array}{c}\text { ALT flare monitoring } \\
\text { Frequency }(\%)\end{array}$}} & \multirow{3}{*}{$\begin{array}{c}\text { Time } \\
\text { interval }^{\mathrm{a}} \\
\text { (range (weeks)) }\end{array}$} \\
\hline & & Method & Regularity & & & \\
\hline & & & & $\begin{array}{l}\text { YMDD variants } \\
\text { related }\end{array}$ & $\begin{array}{l}\text { YMDD variants } \\
\text { non-related }\end{array}$ & \\
\hline Present study & 8 & INNO-LiPA & monthly, since pretreatment & $62.5(5 / 8)^{d}$ & $0(0 / 20)$ & $19(17-21)$ \\
\hline 11 & 12 & DNA sequencing & monthly, after virologic breakthrough ${ }^{b}$ & $\begin{array}{l}91.7(11 / 12)^{\mathrm{e}} \\
50.0(6 / 12)^{f}\end{array}$ & $0(0 / 13)$ & $16(12-104)$ \\
\hline 37 & 43 & INNO-LiPA & $\begin{array}{l}\text { at the time of HBV DNA breakthrough } \\
\text { and at the last follow-up }\end{array}$ & $\begin{array}{l}62.8(27 / 43)^{\mathrm{g}} \\
16.3(7 / 43)^{\mathrm{h}}\end{array}$ & n.a. & $56(0-260)$ \\
\hline 38 & 30 & DNA sequencing & at the time of HBV DNA breakthrough ${ }^{b}$ & $\begin{array}{l}66.7(20 / 30)^{\mathrm{e}} \\
23.3(7 / 30)^{f}\end{array}$ & n.a. & $24(0-104)$ \\
\hline 39 & 15 & DNA sequencing & at intervals of 2 weeks to 3 months & $100(15 / 15)^{i}$ & n.a. & $16(8-40)$ \\
\hline 40 & 32 & $\begin{array}{l}\text { DNA sequencing } \\
\text { and ACRS-PCR + } \\
\text { RFLP }\end{array}$ & $\begin{array}{l}\text { monthly or bimonthly, after virologic } \\
\text { breakthroughc }\end{array}$ & $\begin{array}{l}93.7(30 / 32)^{e} \\
40.6(13 / 32)^{i}\end{array}$ & $4.3(1 / 23)^{i}$ & $24(4-94)$ \\
\hline
\end{tabular}

$\mathrm{N}=$ number of individuals with YMDD variant emergence; $\mathrm{ALT}=$ alanine aminotransferase; $\mathrm{ACRS}=$ amplification created restriction site; $\mathrm{n} . \mathrm{a} .=\mathrm{not}$ available. aSince the detection of YMDD variant development; bevaluated every 3 months and on any occasion of biochemical breakthrough;

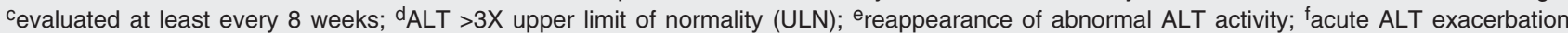

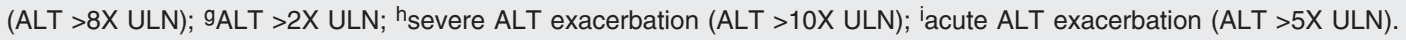


gence should already be started by the 6th month of lamivudine treatment.

An appropriate analytical methodology for the follow-up of HBV variability in patients under long-term lamivudine treatment is available, and the establishment of close clinical and laboratory monitoring schedules for patients with positive detection of resistant strains is feasible. Since the interval between the identification of viral genotypic resistance and possible subsequent biochemical relapse is reasonably long, sufficient time should be available to alter therapy in order to minimize the probability of ALT flare and its associated symptoms. The current availability of adefovir, entecavir and pegylated interferon- $\alpha$, and the promising perspectives offered by drugs such as tenofovir, which are all effective against lamivudine-resistant mutants, have offered new therapeutic choices should first-line lamivudine treatment falter due to the emergence of drug resistance. The present study showed that frequent, regular screening for the presence of hepatitis B virus YMDD mutants in patients undergoing lamivudine therapy could improve treatment options.

\section{Acknowledgments}

We would like to thank Fred Shapiro and Anne Farmer (Innogenetics, Ghent, Belgium) for their excellent help in reviewing the manuscript.

\section{References}

1. Lai CL, Dienstag J, Schiff E, Leung NW, Atkins M, Hunt C, et al. Prevalence and clinical correlates of YMDD variants during lamivudine therapy for patients with chronic hepatitis B. Clin Infect Dis 2003; 36: 687-696.

2. WHO (World Health Organization). Fact Sheet 204. http://www.who. int/mediacentre/factsheets/fs204/en. Accessed December 19, 2006.

3. Lai CL, Ratziu V, Yuen MF, Poynard T. Viral hepatitis B. Lancet 2003; 362: 2089-2094.

4. Hadziyannis SJ, Tassopoulos NC, Heathcote EJ, Chang TT, Kitis G, Rizzetto M, et al. Adefovir dipivoxil for the treatment of hepatitis B e antigen-negative chronic hepatitis B. N Engl J Med 2003; 348: 800807.

5. Marcellin P, Chang TT, Lim SG, Tong MJ, Sievert W, Shiffman ML, et al. Adefovir dipivoxil for the treatment of hepatitis $B$ e antigenpositive chronic hepatitis B. N Engl J Med 2003; 348: 808-816.

6. Chang TT, Gish RG, de Man R, Gadano A, Sollano J, Chao YC, et al. A comparison of entecavir and lamivudine for HBeAg-positive chronic hepatitis B. N Engl J Med 2006; 354: 1001-1010.

7. Lai CL, Shouval D, Lok AS, Chang TT, Cheinquer H, Goodman Z, et al. Entecavir versus lamivudine for patients with HBeAg-negative chronic hepatitis B. N Engl J Med 2006; 354: 1011-1020.

8. Fung SK, Lok AS. Drug insight: Nucleoside and nucleotide analog inhibitors for hepatitis B. Nat Clin Pract Gastroenterol Hepatol 2004; 1: $90-97$.

9. Sociedade Brasileira de Hepatologia (SBH). Consenso sobre condutas nas hepatites virais B e C. GED 2005; 24 (Suppl 1): S1-S16.

10. Dienstag JL, Schiff ER, Wright TL, Perrillo RP, Hann HW, Goodman $Z$, et al. Lamivudine as initial treatment for chronic hepatitis $B$ in the United States. N Engl J Med 1999; 341: 1256-1263.

11. Hadziyannis SJ, Papatheodoridis GV, Dimou E, Laras A, Papaioannou C. Efficacy of long-term lamivudine monotherapy in patients with hepatitis B e antigen-negative chronic hepatitis $B$. Hepatology 2000; 32: 847-851.
12. Lok AS, Lai CL, Leung N, Yao GB, Cui ZY, Schiff ER, et al. Longterm safety of lamivudine treatment in patients with chronic hepatitis B. Gastroenterology 2003; 125: 1714-1722.

13. Lavanchy D. Hepatitis B virus epidemiology, disease burden, treatment, and current and emerging prevention and control measures. $J$ Viral Hepat 2004; 11: 97-107.

14. Lok AS, McMahon BJ. Chronic hepatitis B: update of recommendations. Hepatology 2004; 39: 857-861.

15. Stuyver L, Van Geyt C, De Gendt S, Van Reybroeck G, Zoulim F, Leroux-Roels $\mathrm{G}$, et al. Line probe assay for monitoring drug resistance in hepatitis B virus-infected patients during antiviral therapy. $J$ Clin Microbiol 2000; 38: 702-707.

16. Hussain M, Chu CJ, Sablon E, Lok AS. Rapid and sensitive assays for determination of hepatitis B virus (HBV) genotypes and detection of HBV precore and core promoter variants. J Clin Microbiol 2003; 41: 3699-3705.

17. Hall TA. BioEdit: a user-friendly biological sequence alignment editor and analysis program for Windows 95/98/NT. Nucleic Acids Symp Ser 1999; 41: 95-98.

18. Ganem D, Prince AM. Hepatitis B virus infection - natural history and clinical consequences. N Engl J Med 2004; 350: 1118-1129.

19. Sablon E, Shapiro F. Advances in molecular diagnosis of HBV infection and drug resistance. Int J Med Sci 2005; 2: 8-16.

20. Lok AS, Zoulim F, Locarnini S, Mangia A, Niro G, Decraemer H, et al. Monitoring drug resistance in chronic hepatitis $B$ virus (HBV)infected patients during lamivudine therapy: evaluation of performance of INNO-LiPA HBV DR assay. J Clin Microbiol 2002; 40: 3729-3734.

21. Osiowy C, Giles E. Evaluation of the INNO-LiPA HBV genotyping assay for determination of hepatitis B virus genotype. J Clin Microbiol 2003; 41: 5473-5477.

22. Araujo NM, Mello FC, Yoshida CF, Niel C, Gomes SA. High proportion of subgroup A' (genotype A) among Brazilian isolates of hepati- 
tis B virus. Arch Virol 2004; 149: 1383-1395.

23. Sitnik R, Pinho JR, Bertolini DA, Bernardini AP, Da Silva LC, Carrilho FJ. Hepatitis B virus genotypes and precore and core mutants in Brazilian patients. J Clin Microbiol 2004; 42: 2455-2460.

24. Lai CL, Chien RN, Leung NW, Chang TT, Guan R, Tai DI, et al. A one-year trial of lamivudine for chronic hepatitis B. Asia Hepatitis Lamivudine Study Group. N Engl J Med 1998; 339: 61-68.

25. Schalm SW, Heathcote J, Cianciara J, Farrell G, Sherman M, Willems $B$, et al. Lamivudine and alpha interferon combination treatment of patients with chronic hepatitis B infection: a randomised trial. Gut 2000; 46: 562-568.

26. Da Silva LC, Da Fonseca LE, Carrilho FJ, Alves VA, Sitnik R, Pinho JR. Predictive factors for response to lamivudine in chronic hepatitis B. Rev Inst Med Trop São Paulo 2000; 42: 189-196.

27. Ciancio A, Smedile A, Rizzetto M, Lagget M, Gerin J, Korba B. Identification of HBV DNA sequences that are predictive of response to lamivudine therapy. Hepatology 2004; 39: 64-73.

28. Tong S, Kim KH, Chante C, Wands J, Li J. Hepatitis B virus e antigen variants. Int $J$ Med Sci 2005; 2: 2-7.

29. Matsuda M, Suzuki F, Suzuki Y, Tsubota A, Akuta N, Hosaka T, et al. YMDD mutants in patients with chronic hepatitis $B$ before treatment are not selected by lamivudine. J Med Virol 2004; 74: 361-366.

30. Ono SK, Kato N, Shiratori Y, Kato J, Goto T, Schinazi RF, et al. The polymerase L528M mutation cooperates with nucleotide bindingsite mutations, increasing hepatitis $\mathrm{B}$ virus replication and drug resistance. J Clin Invest 2001; 107: 449-455.

31. Pallier C, Castera L, Soulier A, Hezode C, Nordmann P, Dhumeaux $\mathrm{D}$, et al. Dynamics of hepatitis B virus resistance to lamivudine. $J$ Virol 2006; 80: 643-653.

32. Allen MI, DesLauriers M, Andrews CW, Tipples GA, Walters KA, Tyrrell DL, et al. Identification and characterization of mutations in hepatitis B virus resistant to lamivudine. Lamivudine Clinical Investi- gation Group. Hepatology 1998; 27: 1670-1677.

33. Nogales MC, Serrano MC, Suarez E, Corpas R, Perez L, Claro R, et al. Determination of hepatitis B virus genotype and detection of lamivudine-resistance mutations. Gastroenterol Hepatol 2004; 27: 515-520.

34. Akuta N, Suzuki F, Kobayashi M, Tsubota A, Suzuki Y, Hosaka T, et al. The influence of hepatitis $B$ virus genotype on the development of lamivudine resistance during long-term treatment. J Hepatol 2003; 38: 315-321.

35. Moskovitz DN, Osiowy C, Giles E, Tomlinson G, Heathcote EJ. Response to long-term lamivudine treatment (up to 5 years) in patients with severe chronic hepatitis $\mathrm{B}$, role of genotype and drug resistance. J Viral Hepat 2005; 12: 398-404.

36. Sun J, Wang Z, Ma S, Zeng G, Zhou Z, Luo K, et al. Clinical and virological characteristics of lamivudine resistance in chronic hepatitis B patients: a single center experience. J Med Virol 2005; 75: 391-398.

37. Yuen MF, Yuan HJ, Sablon E, Wong DK, Chan AO, Wong BC, et al. Long-term follow-up study of Chinese patients with YMDD mutations: significance of hepatitis B virus genotypes and characteristics of biochemical flares. J Clin Microbiol 2004; 42: 3932-3936.

38. Papatheodoridis GV, Dimou E, Laras A, Papadimitropoulos V, Hadziyannis SJ. Course of virologic breakthroughs under long-term lamivudine in $\mathrm{HBeAg}$-negative precore mutant HBV liver disease. Hepatology 2002; 36: 219-226.

39. Natsuizaka M, Hige S, Ono Y, Ogawa K, Nakanishi M, Chuma M, et al. Long-term follow-up of chronic hepatitis $B$ after the emergence of mutations in the hepatitis B virus polymerase region. $J$ Viral Hepat 2005; 12: 154-159.

40. Liaw YF, Chien RN, Yeh CT, Tsai SL, Chu CM. Acute exacerbation and hepatitis $B$ virus clearance after emergence of YMDD motif mutation during lamivudine therapy. Hepatology 1999; 30: 567-572. 